\title{
VYBRANÉ INSPIRACE OBSAŽENÉ V PRVNÍCH TŘECH K APITOLÁCH DEI VERBUM PADESÁT LET PO ZAHÁJENÍ KONCILU
}

C T I R A D VÁCLAV POSPÍŠIL

$\mathrm{V}_{\mathrm{r}}$

racet se znovu k dogmatické konstituci II. vatikánského koncilu o Božím zjevení není z několika důvodů právě snadná záležitost. V první řadě platí, že zejména první tři kapitoly tohoto velmi hutného textu hovoří o neuralgických bodech celé křestanské teologie: vymezení pojmu zjevení, problematika předávání zjevení, inspirace. Když konstatujeme, že tohle všechno je denní chleba každého teologa, není to určitě nic objevného. Není proto divu, že se dotýkáme záležitostí, jež jsou - anebo by měly být - každému z nás dủvěrně známy. S tím pak vcelku pochopitelně souvisí jednak nebývalá šíre otázek, jimiž se zmíněná konstituce zabývá, jednak to, že o daném tématu existuje velmi rozsáhlá druhotná literatura. ${ }^{1}$ Lze k dané problematice říci ještě něco nového?

1 Z české původní tvorby připomínáme: AA. VV. II. vatikánský sněm - príprava $a$ průběh. Řím: Křestanská akademie, 1968. (Jedná se o soubor článků, které vycházely v průběhu koncilu nebo těsně po jeho skončení. Publikace má navzdory určitým nedostatkům váhu svědectví o tom, jak byl koncil prožíván v době svého konání.) KREJČÍ, Josef. Slovo Boži. Řím: Křestanská akademie, 1971 (Tento komentář vyšel k pátému výročí od vyhlášení konstituce.) POSPÍŠIL, Ctirad V. Posvátná Tradice podle Dei verbum. Teologické texty 2000, roč. 11, s. 112-113; BROŽ, Jaroslav - MIKULICOVÁ, Mlada. Sborník Katolické teologické fakulty IX. Z konference k 40. výroči Dei verbum konané 15. 11. 2005 na KTF UK v Praze. Praha: Karolinum, 2007; tematikou obsaženou v Dei verbum jsem se navíc poměrně podrobně zabýval v monografii POSPÍŠIL, Ctirad V. Hermeneutika mystéria. Kostelní Vydří - Praha: Karmelitánské nakladatelství - Krystal OP, 32010, s. 72-105. Z překladové literatury je třeba připomenout na prvním místě dokumenty magisteria a také texty PBK. Je evidentní, že tematiky obsažené v Dei verbum se dotýkají i mnohé jiné dokumenty kupříkladu MTK, nicméně v následujícím přehledu se omezujeme pouze na ty, které mají k problematice zjevení a jeho předávání bezprostřední vztah: BENEDIKT XVI. Verbum Domini - posynodni apoštolská exhortace o Božím slově v životě a posláni církve (30. 9. 2010). Kostelní Vydří: Karmeli- 
Z řečeného vyplývá, že je nutno učinit určité volby, protože hovořit o všem by nevyhnutelně vedlo k určité povrchnosti, která by vzdělaného čtenáře rozhodně nemohla zaujmout. Již bylo poznamenáno, že se budeme věnovat pozornost přednostně první polovině dané konstituce, kterou však nemíníme komentovat souvisle, protože takových textů je k dispozici sdostatek. Vybereme tedy zde přítomné nosné inspirace a pokusíme se k nim přistupovat z hlediska současného stavu bádání, což by měl být inovativní moment tohoto příspěvku. ${ }^{2}$ Ospravedlnění nám k tomu poskytuje následující text samotné $D e i$ verbum:

„Vzrůstá totiž chápání předaných věcí a slov, a to jak přemýšlením a studiem věřících, kteří je uchovávají ve svém srdci, tak hlubším pochopením duchovních skutečností z vlastní zkušenosti.“3

Dlužno vzít v potaz, že samu dogmatickou konstituci, která je výrazem nejvyššího magisteria církve, musíme na základě toho, co

tánské nakladatelství, 2011; PAPEŽSKÁ BIBLICKÁ KOMISE. Výklad Bible v církvi. Praha: Zvon, 1996; PAPEŽSKÁ BIBLICKÁ KOMISE. Židovský národ a jeho posvátná Pisma v křestanské Bibli. Kostelní Vydří: Karmelitánské nakladatelství, 2004. Dále upozorňujeme na tituly: PESCH, Otto Hermann. Druhý vatikánský koncil 1962-1965. Praha: Vyšehrad, 1996, s. 262-280; POJAVNIK, Ivan. Mysterium koncilu. Olomouc: MCM, 1998, s. 283-348.

Ačkoliv není rozhodně snadné vybrat několik cizojazyčných titulů z jejich nepřeberného množství, zdálo by se hrubým opomenutím nepřipomenout následující: FELICI, Pericle. Costituzione dogmatica sulla divina rivelazione. In GAROFALO, Salvatore (ed.). Dizionario del Concilio ecumenico Vaticano secondo. Roma: Unedi, 1969, s. 330-346 (tento obsáhlý slovník představuje výjimečné svědectví, protože mnozí přispěvatelé byli přímými a aktivními účastníky prací na koncilních dokumentech); BETTI, Umberto. La Dottrina del Concilio Vaticano II sulla trasmissione della Rivelazione. Roma: Antonianum, 1985 (vynikající monografie přímého aktivního účastníka prací na textu konstituce); LATOURELLE, Rene (ed.). Vaticano II - Bilancio e Prospettive Venticinque anni dopo (1962-1987), 1. sv. Assisi: Cittadela editrice, 1987, s. 125-342 (celkem 13 příspěvků renomovaných odborníků).

2 Obdobný přístup zejména k dogmatické konstituci Lumen gentium je patrný v dokumentu: MEZINÁRODNÍ TEOLOGICKÁ KOMISE. Vybraná témata z eklesiologie. In POSPÍŠIL, Ctirad V. (ed., překlad, úvodní studie). Dokumenty MTK věnované eklesiologii a svátostem do roku 1995 a Dokument PBK Jednota a rozličnost v církvi. Kostelní Vydří: Karmelitánské nakladatelství, 2011, s. 133-186. V tomto textu se 25 let po uzavření koncilu projasňuje řada témat, např́íklad otázka terminologie „partikulárni““ - „místni““ církev, která v koncilních dokumentech není vyjasněna, atd.

3 2. VATIKÁNSKÝ KONCIL. Dei Verbum. In Dokumenty II. vatikánskéko koncilu. Praha: Zvon, 1995. čl. 8, s. 113. 
se v ní nachází, hodnotit jakou součást svědectví ${ }^{4}$ jednak o přítomnosti apoštolské tradice, ${ }^{5}$ jednak o úsilí hlouběji tuto tradici chápat a vnímat, pročež je zcela legitimní po padesáti letech uvažovat nad danými tématy z hlediska toho, co se v teologii v mezidobí odehrálo. Zároveň je zřejmé, že problematice apoštolské tradice je třeba věnovat speciální pozornost. To by nás nemělo překvapovat, nebot́ právě II. kapitola Dei verbum představovala zřejmě nejožehavější téma celého II. vatikánského koncilu. ${ }^{6}$ Vlastnímu zamyšlení nad tajemstvím tradice ovšem předřadíme několik bodů, v nichž se z dnešního hlediska zamyslíme nad vybranými nosnými inspiracemi, a tak zasadíme reflexi tajemství apoštolské tradice do širšího kontextu.

Máme-li v rukou určitý dokument magisteria, musíme se nejprve zamyslet nad stupněm jeho věroučné závaznosti. Jestliže sama konstituce nese kvalifikaci „dogmatická - věroučná“, a nikoliv „biblistická“, pak s tím evidentně souvisí otázka poměru mezi biblickými vědami a dogmatickou teologií. Následně si stručně připomeneme ústřední inspirace obsažené v první a třetí kapitole. Celé pojednání pak dospěje k středobodu našeho zájmu, jímž je právě problematika tradice. V celkově pátém bodu upozorníme na určité možné mariologické inspirace týkající se teologie slova, k nimž nás vybízí nedávno vydaná posynodní exhortace Benedikta XVI. Verbum Domini. V závěru pak upozorníme na přesahy současné teologické reflexe vzhledem k textu koncilní konstituce.

\section{Nevyšší úroveň „třetího koše“?}

Otázka stupně závaznosti nauky obsažené zejména v dogmatických konstitucích II. vatikánského koncilu se zcela pochopitelně objevila již v době koncilních jednání. Pokud se jedná přímo o Dei verbum, generální sekretář koncilu, arcibiskup Pericles Felici, na ni

4 Jestliže platí: „Výroky svatých otců svědčí o oživující přítomnosti této tradice, jejíž bohatství se přelévá do praxe a do života věřící a modlící se církve“ (tamtéž), pak by totéž mělo platit o díle otců shromážděných na II. vatikánském koncilu.

5 Srov. tamtéž, čl. 7, s. 112.

6 „Není riskantní tvrdit, že dogmatická konstituce Dei verbum je nejkvalifikovanějším dokumentem II. vatikánského koncilu, a to přinejmenším proto, že příprava zmíněného dokumentu se odehrávala počas všech zasedání koncilu. [...] Ze šesti kapitol Dei verbum byla právě ta druhá již od samého začátku nejvíce oponována a také nejpečlivěji vyhodnocována.“ BETTI, Umberto. La Dottrina, s. 9-10. 
odpovídá krátkým textem s titulem „Notificatio“ ze dne 15. listopadu $1965 .{ }^{7}$ Kriticky je třeba poznamenat, že tento důležitý text bývá obvykle v překladech dokumentů obsažen, v české verzi ho však hledáme marně. Domnívám se, že v příštích edicích by bylo záhodno právě zmíněný nedostatek odstranit.

V první řadě se v „Notificatio“ konstatuje, že koncil má pastorální zaměření, a proto koncilní otcové chtějí výslovně definovat záležitosti týkající se víry a mravů jen tehdy, pokud je to výslovně uvedeno. V Dei verbum ovšem nemáme žádnou explicitní kvalifikaci ohledně dogmatické definice v úzkém slova smyslu ve formě „definujeme, prohlašujeme...“. Zároveň se ale v „Notificatio“ tvrdí, že všechno, co tento dokument jakožto výraz nejvyššího magisteria tvrdí, jsou věřící povinni přijmout podle úmyslu koncilních otců, a to v souvislosti s principy teologické interpretace.

Přiznejme si, že odpověd' vyznívá na první pohled poněkud záhadně. V dané souvislosti je záhodno připomenout, že v letech těsně po koncilu se objevilo mínění, podle něhož by II. vatikánský koncil předložil vlastně dvě nová dogmata, konkrétně o svátostnosti biskupského svěcení ${ }^{8}$ a právě o problematice apoštolské tradice. Problém ale tkví v tom, že dogma je pravda zjevená, a proto nevyhnutelně vyvstává otázka, jak dokladovat zjevený charakter reflexe nad tajemstvím tradice? U svátostného rázu biskupského svěcení by dané prokazování zřejmě nepředstavovalo tak zásadní problém. Každopádně ale platí, že samo magisterium ve svých následujících dokumentech o prohlášení nových dogmat na II. vatikánském koncilu nehovoří. At̉ už bude hodnocení stupně závaznosti těchto bodů nauky II. vatikánského koncilu v budoucnu jakékoli, určitě platí to, co stojí v LG, čl. 25, totiž že věřící má povinnost přilnout k výrokům nejvyššího magisteria i tehdy, nevystupují-li jeho nositelé „ex cathedra“.

Zamyslíme-li se nad kvalifikací dogmatické závaznosti Dei verbum z hlediska Doktrinálního komentáre J. Ratzingera, který vyšel

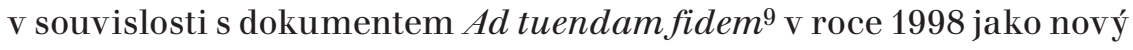

7 Tedy pouhé tři dny před závěrečným hlasováním, které se odehrálo dne 18. listopadu 1965. Z 2350 přítomných 2344 vyslovilo „placet“ a jen 6 „non placet“. Srov. tamtéž, s. 229-230.

8 Srov. BETTI, Umberto. La dottrina sull'episcopato del Concilio Vaticano II. Il capitolo III della Costituzione dogmatica Lumen gentium. Roma: Antonianum, 1984.

9 Srov. JAN PAVEL II. Ad tuendam fidem - motu proprio (18. 5. 1998). Text Doktrinálního komentáre je součástí dokumentu KONGREGACE PRO NAUKU VÍRY. Vyznání víry a prísaha vérnosti, původně ze dne 25 . února 1989, který vyšel znovu v souvis- 
výraz toho, jak magisterium chápe sebe samo, pak se mi osobně jeví, že nauka této dogmatické konstituce patří do tak zvaného „třetího koše“. Jedná se tudíž o výroky řádného univerzálního magisteria, které nejsou ani prohlášením nějaké pravdy za zjevenou (dogma), ani prohlášení nějaké nauky jako definitivní. To pochopitelně otvírá cestu k dalšímu rozvíjení předložené nauky, ale zároveň nás ve svědomí zavazuje k tomu, abychom takovou nauku přijímali „s uctivostí rozumu a víry“.

Právě zmíněné kvalifikaci bývá někdy rozuměno ne zcela správně, protože se nejedná pouze o přilnutí na základě čiré vůle, nýbrž také na bázi zdravého rozumu osvíceného vírou. Magisteriální texty posledních desetiletí totiž mají výrazně přesvědčovací a argumentační ráz, který apeluje na soudnost adresátů. Řečeno jinak, výroky učitelského úřadu, mají být přijímány nikoliv jako cosi přednostně heteronomního a autoritativního, nýbrž spíše - pokud to zralost adresáta umožňuje - autonomním způsobem, tedy na základě souzvuku mezi výrokem a více či méně vybroušeným smyslem pro víru, jímž je věřící vybaven.

Dané konstatování ohledně příslušnosti Dei verbum do tak zvaného třetího koše však vrhá světlo i na obsah samotného Doktrinálniho komentáre, protože zde zmíněný třetí koš bude mít s velkou mírou pravděpodobnosti celou řadu úrovní, což však v příslušném dokumentu není uvedeno. ${ }^{10}$ Každý jistě pochopí, že encyklika nebo posynodní exhortace, jakožto typický formát dokumentů třetího koše, bude mít výrazně nižší úroveň než formát „dogmatické konstituce“ ekumenického koncilu. Nezapomínejme, že církevní dokument nesoucí označení „konstituce“ („bulla“) má pro církev obdobnou váhu jako „ústavní zákon“ v rámci státního zákonodárství. Není také náhodou, že nová dogmata se v posledních staletích objevovala právě v dokumentech tohoto druhu.

Toto hodnocení věroučné závaznosti Dei verbum je ovšem pouze soukromým míněním autora tohoto příspěvku. Pokud by samo magisterium v budoucnu kvalifikovalo hodnotu nauky obsažené

losti s Ad tuendam fidem. Proto má tento Doktrinální komentář datum 29. června 1998. Český překlad In POSPÍŠIL, Ctirad V. Hermeneutika mystéria, s. 204-209.

10 Dvě úrovně jsou ale přece jenom v jistém slova smyslu naznačeny, když se hovoří o řádném univerzálním (papež spolu s biskupy, případně papež sám) a o řádném magisteriu jednotlivých biskupů. Není zde ale řečeno nic o různých úrovních řádného univerzálního magisteria. 
v Dei verbum jinak, je evidentně třeba to přijmout, protože autentický výklad textů magisteria přísluší právě jejich autorovi, jímž je magisterium.

Pokud by právě nastíněná nevyjasněnost připadala někomu podivná či svízelná, měl by vzít v potaz, že magisterium není primárně akademickou záležitostí, nýbrž projevem života církve, který - jak každý dobře pochopí - nelze vměstnat do přesných šablon. Ona záhadnost má však jednu nespornou výhodu, která tkví v otevřenosti budoucnosti. Lidští autoři textu ponechávají v jistém slova smyslu své výroky otevřené příštím novočtením (relekturám), která budou záviset na dalším běhu dějin spásy. Biblicky vzato platí, že otevřenost budoucnosti a dalším novočtením (relekturám) dává prostor samotnému Pánu dějin, aby dal najevo, v čem jeho myšlení překračuje myšlení člověka. Právě nastíněná otevřenost textů magisteria se projevuje kupříkladu i v používané terminologii. Není tajemstvím, že v př́ípadě trojičního, christologického či eucharistického dogmatu se aplikují termíny pocházející z oblasti filosofie. Magisterium ale tyto použité výrazy nikdy jednoznačně nevysvětluje, protože daná „nevyjasněnost“ dává možnost budoucím posunům v interpretaci textů ze strany teologie i magisteria samotného. Dogma tak zůstává ukazatelem na cestě směřující ke stále hlubšímu porozumění nevýslovnému tajemství, které dojde svého naplnění až v eschatologické plnosti. Právě nastíněná otevřenost souvisí evidentně také s myšlenkou koncilních otců, kterou jsme již výše uvedli, totiž že chápání tradice $\mathrm{v}$ dějinách spásy narůstá. ${ }^{11}$

\section{Biblické vědy a dogmatická teologie}

Určitě bychom neměli přejít bez povšimnutí, že tato konstituce je kvalifikována jako „dogmatická“, a nikoliv jako „biblistická“. Určitě není tajemstvím, že v předkoncilních dobách se dogmatičtí teologové chovali k biblistům přezíravě, a proto bychom mohli hovořit o určité „prepotenci“ dogmatiků vůči biblistům. Následné období se neslo zase ve znamení snahy vyvozovat úplně všechno ze zkoumání biblického textu moderními historicko-kritickými a strukturalistickými

11 2. VATIK ÁNSKÝ KONCIL. Dei Verbum, čl. 8, s. 113. 
metodami, jako kdyby dogmatická teologie musela pouze opakovat to, co přinášejí biblisté. ${ }^{12}$

Obě zmíněné podoby ancillarity je však třeba ve jménu zdravého rozumu jednoznačně odmítnout. Neplatí totiž pouze to, že dogmatik musí vycházet z Božího slova, ale zároveň to, že biblista přistupuje ke zjevenému textu na základě určitého předporozumění, které se týká například pojetí inspirace, chápání poměru mezi vlastní vypovídací hodnotou lidského slova Písma a tím, co daným slovem chce vyjadřovat Bůh. ${ }^{13}$ Není jistě náhodou, že teologicky kompletní výklad Písma nastíněný koncilními otci nese jasné rysy dogmatické lektury, když se předtím nastínily základní obrysy exegetické lektury typické pro historicko-kritickou interpretaci, která bere v potaz literární druhy:

„Protože se však má Písmo svaté číst a vykládat v témž Duchu, ve kterém bylo napsáno, v zájmu správného vystižení smyslu posvátných textů je třeba neméně pečlivě přihlížet $k$ obsahu a jednotě celého Písma a přitom mít na zřeteli živou tradici víry a analogii víry.“14

Lze tudíž tvrdit, že dogmatická konstituce klade čistě exegetickou a dogmatickou lekturu vedle sebe, přičemž pořadí obou zmíněných přístupů i zacílení k odhalování toho, co chce daným slovem říci sám Nejvyšší, ukazuje na určité zaměření exegeze a biblické teologie k dogmatice. ${ }^{15}$

12 Jako student doktorského programu na papežské univerzitě Antoniamum v Římě, kde jsem pobýval v první polovině devadesátých let minulého století, jsem tuto situaci určité metodologické bezradnosti ze strany dogmatiků vzhledem k přínosům biblických věd zakoušel velmi intenzivně. V době celého studia mi nebyl nabídnut ani jeden kurs, který by danou problematiku objasňoval.

13 „Protože však Bůh mluví v Písmu svatém prostřednictvím lidí lidským způsobem, musí vykladač Písma svatého, chce-li pochopit, co nám chtěl Bủh sdělit, pozorně zkoumat, co měli svatopisci skutečně v úmyslu vyjádřit a co chtěl jejich slovy zjevit Bůh." 2. VATIKÁNSKÝ KONCIL. Dei Verbum, čl. 12, s. 116.

14 Tamtéž.

15 V tomto ohledu není bez významu, co nacházíme v: BENEDIKT XVI. Verbum Domini, čl. 30, s. 48:

"Přístupy k posvátnému textu, které nedbají na víru, mohou přicházet se zajímavými postřehy, když setrvávají u struktury textu a jeho forem; takové úsilí je však nevyhnutelně předběžné a nehotové.“

V čl. 34 (s. 52) jsme vybízeni k tomu, abychom Písmo vykládali na základě jednoty Písma, v souvislosti s živou tradicí a na základě analogie víry, což jsou prvky zejména dogmatické lektury Božího slova. Následně se konstatuje: 
Máme-li shrnout právě uvedené, pak se zdá, že poměr mezi biblickými vědami a dogmatikou by měl mít povahu hermeneutického kruhu. ${ }^{16}$ Dogmatik totiž musí brát vážně přínosy biblických věd, zejména pak to, na čem se obec biblistů více méně shodne. Naproti tomu exegeta by zase měl vycházet z předporozumění, které je formováno přednostně na poli dogmatické lektury zjevení jako takového, zjevení v jeho zpravidla paradoxální komplexnosti. Jakost dogmatické reflexe i biblistické exegeze bude pochopitelně v mnohém záviset na tom, jak kvalitní biblistika bude př́tomna $\mathrm{v}$ dogmatice a jak vytříbená dogmatická reflexe bude obsažena v kořenech biblistiky. ${ }^{17}$

Právě uvedené pojetí poměru obou teologických disciplín není pouze teoretickou záležitostí, protože nesporně ovlivňuje také spiritualitu biblisty potažmo dogmatika. Zároveň se také ukazuje, v čem tkví nepopiratelný posun současné teologie vzhledem k teologické reflexi v době konání koncilu: ten tkví především v nepoměrně vyšší úrovni promítání přínosů vědecké hermeneutiky do práce současných teologů i v promýšlení hermeneutických specifik našeho vlastního vědního oboru.

Konstatované vede $\mathrm{k}$ tomu, že bychom se neměli podivovat, když o daných tématech pojednávají jak biblisté v úvodu do studia Písma svatého, tak systematičtí teologové na poli fundamentální či dogmatické teologie. Vzhledem k tomu, že fundamentální teologie bývala definována také jako „dogmatica generalis“, a vzhledem k tomu, že samo pojednání o pramenech teologického poznání stojí obvykle až na konci výkladu celé oblasti, která spadá do kompetence fundamentální teologie, je třeba podotknout, že v tomto posledním traktátu se již neaplikuje čistě historicko-kritická metoda, nýbrž v zásadě již metoda dogmatická, protože v předchozích pojednáních byla vyargumentována věrohodnost jednak Ježíšova nároku na to, že je Božím

„Ale zatímco současná akademická exegeze, včetně katolické, pracuje na vysoké úrovni co do historicko-kritické metodologie včetně jejích nejnovějších doplňkủ, je nezbytné vyžadovat podobné studium teologického rozměru biblických textů..." (s. 53).

Synodní otcové tedy vnímají, že v současnosti se nedostatečně rozvíjí dogmatická lektura Písma svatého ve smyslu inteligence víry, a proto nás k tomuto kroku důrazně povzbuzují.

16 Analogicky se na tomto místě můžeme opřít o encykliku: JAN PAVEL II. Fides et ratio - Encyklika o vztazich mezi vírou a rozumem (14.9. 1998), čl. 72. Český překlad Praha: Zvon, 1999, kde se pomocí schématu hermeneutického kruhu popisuje poměr mezi teologií a filosofií.

17 Podrobněji o dané záležitosti hovořím v: POSPÍŠIL, Ctirad V. Hermeneutika mystéria, s. 31-33. 
poslem, jednak to, že církvi bylo svěřeno poslání autenticky vykládat zjevení. Označení konstituce jako „dogmatická“ tak dostává poslední systematicko-teologické oprávnění z hlediska pojednávané látky i z hlediska formálního přístupu k dané tematice. Výraz „dogmatická“ má v tomto případě ještě další oprávnění, které tkví v tom, že se jedná o výkon magistera, který má nespornou věroučnou váhu a také výše specifikovanou závaznost pro všechny věřící, mezi něž patří bezesporu i ti, kdo se z různých hledisek odborně věnují studiu Božího slova a problematice předávání Božího zjevení v dějinách Božího lidu.

\section{Některé kapitální inspirace obsažené v první a třetí kapitole Dei verbum}

Když pročítáme první kapitolu, hned ve druhém článku nacházíme velmi zajímavé konstatování, které se podle koncilních otců týká celého zjevení, tedy i Starého zákona, protože se hovoří o zjevení jako takovém:

„Bůh se ve své dobrotě a moudrosti rozhodl zjevit sebe samého a oznámit tajemství své vůle: že lidé prostřednictvím Krista, vtěleného Slova, mají

v Duchu svatém přístup k Otci a stávají se účastni božské přirozenosti.“18

Nejsem si jist, zda sami otcové shromáždění na koncilu si plně uvědomovali obrovskou potencialitu tohoto tvrzení. Konstatované totiž implikuje, že Jahve je Bůh Otec, kterého však nikdy nemůžeme poznávat bez Syna a Ducha svatého, i když to ve Starém zákoně svatopiscům a Božímu lidu nemohlo být zcela zřetelné. ${ }^{19}$ Trojice je tedy jednotícím principem celého zjevení, které není oznamováním něčeho, nýbrž zjevováním samotného Boha, ${ }^{20}$ čili jeho sebedarováním. Je-li cílem zjevení primárně sebedarování Trojjediného člověku, pak také teologie musí být teocentrická a antropocentrická zároveň, což je možné jedině za předpokladu trojiční lektury Písma. V Troji-

18 2. VATIKÁNSKÝ KONCIL. Dei Verbum, čl. 2, s. 109.

19 Srov. POSPÍŠIL, Ctirad V. Jako v nebi, tak i na zemi. Náčrt trinitární teologie, 2. vydání. Kostelní Vydří - Praha: Karmelitánské nakladatelství - Krystal OP, 2010, s. 21-46.

20 Srov. 2. VATIKÁNSKÝ KONCIL. Dei Verbum, čl. 6, s. 110. 
ci totiž Syn klade na první místo Otce, jehož napodobuje v tom, že Otec důsledně klade na první místo Syna a v něm nás samotné. Dialogický teocentrismus a dialogický antropocentrismus se nejenom vzájemně nevylučují, ale dokonce se nevyhnutelně podmiňují a vzájemně prostupují.

Právě komentované místo navíc plně souzní s tím, co nacházíme v Katechismu katolické církve, čl. 234, ${ }^{21}$ kde se dozvídáme, že tajemství Boha Otce, Syna a Ducha svatého je první a základní pravdou křestanské víry a křestanského života a že všechny ostatní pravdy víry máme nahlížet ve světle trojičního mystéria. Tento vznešený ideál je třeba i dnes vnímat jako výzvu k další práci, protože stav současné teologické reflexe je ještě na hony vzdálen tomu, co se zde proklamuje.

Dlužno však podotknout, že slova koncilních otců by bylo možno doplnit. Neplatí snad, že Krista jako Pána poznáváme jedině díky působení Ducha svatého (srov. 1Kor 12,3)? Nezjevuje snad vtělený Syn Otce (srov. Mat 11,27) a také Ducha svatého (srov. Jan 14-15-16)? Nezjevuje Duch Otce (srov. 1Kor 2,10-11) i Syna (srov. 1Kor 12,3)? ${ }^{22}$ Z řečeného vyplývá, že základní princip trojičně chápaného zjevení - sebedarování Trojjediného tkví v tom, že osoba Trojice nikdy neukazuje primárně na sebe, nýbrž na druhé dva. Proto také nedialogicky pojímané historicko-kritické bádání o Ježíšovi z Nazareta, které nebere $\mathrm{v}$ potaz pneumatologickou fázi zjevení, navzdory určitým dílčím pozitivním přínosům, nevyhnutelně musí končit ve slepé uličce, jak to konec konců dokládají dějiny bádání o historickém Ježíšovi v 19. století (Old Quest), z čehož by si měli vzít poučení četní dnešní badatelé.

Druhá stěžejní inspirace se nachází v témže článku dogmatické konstituce o zjevení:

21 Katechismus katolické cirkve. Kostelní Vydří: Karmelitánské nakladatelství, 2001, s. $73-74$.

22 Jestliže zjevení je primárně sebedarování Trojjediného, pak není divu, že celá ekonomie zjevování je primárně v režii Ducha svatého, jenž je přece Boží přirozeností jakožto zosobněný Dar, a to jak v imanentní Trojici, tak v Trojici ekonomické. „Můžeme říci, že v Duchu svatém je vnitřní život trojjediného Boha veskrze darem, vzájemnou láskou mezi božskými osobami, a že skrze Ducha svatého existuje Bůh jako Dar. On je Osoba-láska, je Osoba-dar.“ JAN PAVEL II. Dominum et vivificantem - Encyklika o Duchu svatém v životě církve a svéta (18. 5. 1986), Praha: Zvon, 1997, čl. 10, s. 16. 
„Toto zjevování se uskutečňuje činy i slovy, které navzájem vnitřně souvisí, takže skutky, které Bůh vykonal v dějinách spásy, ukazují a posilují nauku i skutečnosti vyjádřené slovy; slova pak hlásají tyto skutky a objasňují tajemství v nich obsažená.“23

Katolická teologie tedy odmítá jak redukci zjevení na pouhé skutečnosti a fakta (Old Quest), tak bultmannovskou restrikci zjevení na pouhé slovo Písma, což je specifická verze jednostranné aplikace principu „sola Scriptura“. Stojíme tak před klasickým příkladem bipolárního paradoxu vymezeného dvěma extrémy, mezi nimž se nachází pole legitimního teologického pluralismu. Zjevení tudíž nejsou ani sama holá fakta, ani samo slovo Písma, nýbrž obojí zároveň. Na tomto místě si dovolím podotknout, že potencialita výroku koncilních otců jde opět mnohem dál, než si zřejmě oni sami uvědomovali, protože zmíněný princip platí i pro dějiny obecně. Dějiny totiž nejsou ani pouze striktně objektivisticky pojímaná fakta, ani výlučně jejich nevyhnutelně subjektem historika poznamenaná interpretace, nýbrž obojí. V dějinách totiž jednají subjekty, a proto se jedná o subjekto-objektovou skutečnost. Dalo by se také říci, že dějiny mají zřetelně fenomenickou povahu. ${ }^{24}$

V prvním odstavci 4 . článku ${ }^{25}$ nacházíme tvrzení, podle něhož Kristus svým životem, dílem, utrpením, vzkříšením a sesláním Ducha svatého představuje dovršení celého zjevení. Vzhledem k tomu, co bylo řečeno výše o povaze zjevení, které sestává z Božích skutků v dějinách spásy a následně také ze slov, je zřejmé, že nyní padá důraz na samu skutečnost vtělení v jeho dynamickém rozměru stávání se člověkem, takže toto vtělení se dovršuje právě v okamžiku, kdy je všechno dokonáno (srov. Jan 19,30) a Slovo vstupuje do hlubiny lidské smrti. Z řečeného jasně vyplývá, že samo tajemstvím vtěleného Slova stojí nad lidským slovem Písma. Je-li Kristus jedením z Trojice, pak jeho tajemství musí být v posledním důsledku nevýslovné. Jak ale zvěstovat to, o čem se adekvátně hovořit nedá? Jedině prostřednictvím plurality novozákonních christologií, které se vzájemně korigují, kompletujíi ${ }^{6}$ a hlavně nás chrání před jed-

23 2. VATIKÁNSKÝ KONCIL. Dei Verbum, čl. 2, s. 109.

24 Srov. POSPÍŠIL, Ctirad V. Ježiš Kristus - Pravda dèjin. Trojiční a christocentrická teologie déjin, Kostelní Vydří: Karmelitánské nakladatelství, 2009, s. 70nn.

25 Srov. 2. VATIKÁNSKÝ KONCIL. Dei Verbum, čl. 2, s. 110.

26 Srov. PAPEŽSKÁ BIBLICKÁ KOMISE, Bible a christologie, Praha: Krystal OP, 1999, čl. 2.2.2.2.c, s. 66 . 
nostrannou ideologizací tajemství samotného. ${ }^{27}$ Právě toto vědomí některým christologiím současných autorů očividně schází, a proto jejich autoři bohužel upadají do nebezpečných partikularismů zavánějících jednostranností a následně také ideologizací poselství Nového zákona o Muži z Nazareta.

Ve druhém odstavci článku č. 4 nacházíme další bezesporu trvale aktuální výrok:

„Křestanské dílo spásy tedy jako nová a konečná úmluva nikdy nepomine a nemůžeme očekávat už žádné nové veřejné zjevení před slavným příchodem našeho Pána Ježíše Krista.“28

Vzhledem k tomu, že fenomén tak zvaných soukromých, přesněji aktualizačních zjevení, se v posledních desetiletích stal opravdovou výzvou pro náš rozum, ${ }^{29}$ je nabíledni, že právě na toto konstatování se dnes musí klást velký důraz. Rozhodně není bez zajímavosti, že koncilní dokumenty se o „soukromých“ - aktualizačních zjeveních v zásadě nevyjadřují. Implicitně se jich týká jen toto místo. Rozhodně ale nejde o nějakou novou nauku, nýbrž o výraz trvalého postoje církev k těmto jevům. ${ }^{30}$

V čl. 6 se hovoří poměrně lakonicky o přirozeném zjevení. Koncilní otcové konstatují, že to, co může lidský rozum o Božích záležitostech poznat přirozenou cestou, nyní díky biblickému zjevení poznáváme snadno, s pevnou jistotou a bez přimíšení omylu. ${ }^{31}$ Koncilní otcové se v dané záležitosti odvolávají pochopitelně na Řím 1,20. Mohli ovšem odkazovat také na Mdr 13,5. Současná katolická teologie sice nepopírá nic z toho, co je zde řečeno, nicméně je mnohem skeptičtější například k tak zvaným „důkazům Boží existence“, než jak tomu

27 V této věci si dovolím poukázat na výrok MTK: „Jednota víry a pluralita jejích vyjádření mají svůj poslední základ v tajemství samotného Krista, které, ačkoli je tajemstvím univerzálního usmíření a obnovy, nápravy, shrnutí, překračuje výrazové prostředky každé historické epochy, a proto se vymyká jakékoli vyčerpávající systematizaci.“MEZINÁRODNÍ TEOLOGICKÁ KOMISE, Jednota víry a teologický pluralismus. In POSPÍŠIL, Ctirad V. (ed.). Dokumenty MTK věnované metodè do roku 1995 a statuta MTK. Olomouc - Kostelní Vydří: CMTF UP - Karmelitánské nakladatelství, čl. 1, s. 15.

28 2. VATIKÁNSKÝ KONCIL. Dei Verbum, čl. 4, s. 110.

29 Určitě není bez významu, že v dokumentu Verbum Domini je tomuto tématu věnována druhá část, čl. 14, s. 30-31).

30 Srov. POSPÍŠIL, Ctirad V. K problematice soukromých - aktualizačních - zjevení. Teologické texty, 2010, č. 4, s. 170-180

31 Srov. 2. VATIKÁNSKÝ KONCIL. Dei Verbum, čl. 6, s. 111. 
bylo v minulosti. Víme také, že na základě těchto dokazování nikdo nedospěje k víře, která je přece osobním setkáním s Otcem v Kristu a Duchu svatém. Máme ještě v paměti to, jak hrubě neblaze působilo nadřazování přirozené teologie Božímu zjevení. 32 Pokud mají hrát v našem uvažování o Bohu tyto věci odpovídající roli, pak jedině jako něco, co přichází po vlastním aktu víry jako dodatečné potvrzení, že učiněný krok není proti rozumu. ${ }^{33}$

V dané souvislosti je třeba podotknout, že v posynodní exhortaci Benedikta XVI. Verbum Domini, čl. 8-10 ${ }^{34}$ se přirozené zjevení jasně hodnotí nikoli jako něco nezávislého na zjevení biblickém a rozhodně zde není ani náznak toho, že by se přirozené zjevení v jistém ohledu předřazovalo onomu nadpřirozenému, nýbrž přesně naopak jsme vybízeni k tomu, abychom knihu stvoření vnímali na základě slov Písma a především na základě tajemství vtěleného Slova.

O některých inspiracích obsažených ve třetí kapitole jsme se již museli zmínit výše, nyní se tedy zaměříme na ty, jichž jsme se prozatím ještě nedotkli. V první řadě je to následující výrok:

„Protože tedy všechno, co tvrdí inspirovaní autoři neboli svatopisci, se musí považovat za tvrzení Ducha svatého, je třeba uznat, že knihy Písma učí spolehlivě, věrně a bez omylu pravdu, kterou chtěl mít Bůh zaznamenanou v Písmu pro naši spásu. “35

Pozornému čtenáři neunikne, že poznámka s odkazy na magisteriální dokumenty a na díla církevních učitelů se nachází za slovem „pravdu“, vlastní vymezení neomylnosti Písma soteriologickým zacílením však odkazem na dřívější svědky tradice vybaveno není

32 Jako př́klad můžeme uvést dílo: BÁRTA, Jan B. Syntéza učení víry I, II, III. Praha: Sekretariát řeholních společností v ČSSR, 1969, 317 stran; reedice v jediném svazku: Praha: Řád, 1991, 301 stran. Na stranách 46-61 je čtenář seznámen s přirozeným poznáním Boha. Na stranách 97-98 se pak tvrdí, že nadpřirozené zjevení v zásadě jen potvrzuje to, co člověk o Bohu může poznat svým rozumem. O Trojici se v díle nepojednává.

33 „Není to přirozená teologie, která by byla základem víry, ale je to spíše víra, která motivuje přirozenou teologii. [...] UUkol přirozené teologie spočívá v tom, že prokazuje nárok víry na rozumnost a univerzalitu.“ KASPER, Walter. Der Gott Jesu Christi. Mainz: Matthias-Grünewald-Verlag, 1982, s. 105-106. Srov. LOBKOWICZ, Mikuláš. Důkazy Boha a rebus creatis. Volná skica historických pozorování a logických úvah. Teologické texty. 2007, s. 63-68, zde s. 66.

34 Český překlad, s. 20-25.

35 2. VATIKÁNSKÝ KONCIL. Dei Verbum, čl. 11, s. 115. 
a určitě souvisí s celkovým laděním této dogmatické konstituce. ${ }^{36}$ Je tudíž evidentní, že Písmo není neomylné v každém ohledu, a proto je daným vymezením zásadně odmítnuta fundamentalistická četba Bible, ${ }^{37}$ což má pochopitelně velký význam například pro oblast dialogu mezi vírou a př́rodními vědami. Hledáme-li to, co chtěl lidským, a proto nevyhnutelně v mnoha ohledech historicky a kulturně podmíněným lidským slovem sdělit sám Bůh, ${ }^{38}$ pak se toto zkoumání zaměřuje především na oblast soteriologie v širokém smyslu slova, což znamená, že vlastně celá teologie má přednostně soteriologické zacílení.

Dané vymezení neomylnosti Písma by se mohlo analogicky opřít o učení I. vatikánského koncilu, který učí, že v oblasti analogie víry máme brát v potaz nejenom vazby mezi jednotlivými pravdami víry, nýbrž vždy zcela zásadně podtrhovat rovněž jejich poměr k poslednímu cíli člověka. ${ }^{39}$ Dále si dovolím poznamenat, že jasné soteriologické zacílení celého Písma ve svém myšlení velmi důrazně podtrhoval vynikající křestanský teolog a církevní učitel ze 13. století Bonaventura z Bagnoregia, takže koncilní otcové mohli v odkazu při této př́ležitosti zmínit např́íklad jeho prolog ke spisu Breviloquium. ${ }^{40}$ Konec konců Benedikt XVI. ve své posynodní exhortaci Bonaventuru několikrát cituje. ${ }^{41}$

Na tomto místě si dovolím ještě jednu poznámku, která souvisí také s dalším zajímavým krokem koncilních otců. V čl. 13 se totiž říká:

„Boží slova totiž, vyjádřená lidskými jazyky, se připodobnila lidské mluvě, jako se kdysi Slovo věčného Otce stalo podobným lidem, když na sebe vzalo slabé lidské tělo.“42

Koncilní otcové tu nastiňují na základě analogie víry strukturální souvislost mezi vtěleným Slovem a slovem Písma. I Bible má dva původce, totiž Boha a člověka, stejně jako Kristus je Synem nebeského

\footnotetext{
36 Srov. např̀. 2. VATIKÁNSKÝ KONCIL. Dei Verbum, čl. 3, s. 109.

37 Srov. BENEDIKT XVI. Verbum Domini, čl. 44, s. 65-66.

38 Srov. 2. VATIKÁNSKÝ KONCIL. Dei Verbum, čl. 12, 1, s. 115-116.

39 Srov. 1. VATIKÁNSKÝ KONCIL. Dei Filius, kap. 4. DSH, č. 3016.

40 Srov. BONAVENTURA. Breviloquium - Kompendium scholastické teologie. Praha: Vyšehrad, 2004, s. 55nn.

41 Srov. BENEDIKT XVI. Verbum Domini, čl. 10, s. 24-25; čl. 23, s. 41, čl. 29, s. 46.

42 2. VATIKÁNSKÝ KONCIL. Dei Verbum, čl. 13, s. 116.
} 
Otce a Marie. Ponechme zatím stranou implicitní mariologickou inspiraci, která by mohla vrhat světlo na oblast teologie Božího slova, a zaměřme se na christologickou stránku daného výroku.

Daná vazba v první řadě bezprostředně ladí s výše zmíněným jasným odmítnutím fundamentalistického či fideistického přístupu k posvátnému textu a se soteriologickým vymezením neomylnosti Písma, přičemž to zároveň implicitně znamená, že lidské slovo Bible je zároveň historicky a kulturně podmíněno. Jestliže vtělení Slova bylo nejenom do lidství, ale také do určité kultury a doby, pak také inspirované slovo Boží představuje nevyhnutelně určité „vtělení“ do určité doby, kultury, lidské vzdělanosti. ${ }^{43}$

S tím následně souvisí také otázka mezí lidského vědění a poznání Ježíše z Nazareta, která se velmi naléhavě objevila před katolickými christology v prvních desetiletích po koncilu. Z toho, co koncilní otcové tvrdí směrem k Písmu, se ovšem dá poměrně snadno vytěžit i vymezení neomylnosti Kristova lidského vědění a poznání: Ježíš ví bezpečně a s jistotou všechno to, co je třeba k naplnění díla naší spásy, v ostatních věcech byl skutečným člověkem své doby a kultury svého národa, a proto jeho obraz světa a př́padně historické poznání bylo také odpovídajícím způsobem podmíněno. ${ }^{44}$ Realita vtělení nás vskutku zaráží jak opravdovostí Božího sklonění se k nám, tak hloubkou kenóze Božího Syna.

\section{Problematika tradice, zejména pak její vlastní povahy v Dei verbum a dnes}

Jestliže jsme konstatovali, že zrod zejména druhé kapitoly Dei verbum byl opravdu svízelný, pak jádrem sporu byla právě tematika, již se nyní chceme zabývat, totiž vymezení povahy tradice, jejího obsahu a zejména jejího poměru k Písmu. Uvážíme-li, co bylo ve hře, není se opravdu čemu divit. S danou problematikou totiž úzce souvisí ekumenický dialog s evangelickými církvemi, které se hlásí k principu „sola Scriptura“. Dlužno však podotknout, že Martin Luther

43 Vtělení Slova „bylo rovněž v tělením do kultury“. JAN PAVEL II. Discorso ai docenti dell'Università di Coimbra a gli uomini di cultura ze dne 15. května 1982. In Insegnamenti di Giovanni Paolo II V/2, Città del Vaticano: Libreria ed. vat., 1982, čl. 5, s. 1695.

44 Srov. POSPÍŠIL, Ctirad V. Problematika vědění a vědomi vlastní osobní identity Ježiše z Nazareta. Olomouc: Refugium, 1998. 
neodmítal všechna podání, ale jen ta, která neměla základ v Písmu. ${ }^{45}$ Na druhé straně však stála nauka tridentského koncilu o „tradicích“ jako výraz katolické identity. ${ }^{46}$

Prvním dokumentem katolického magisteria, kde se objevuje výraz „tradice“ v jednotném čísle, je encyklika Pia XII. Humani generis, ze dne 12. srpna 1950. Vedle tohoto terminologického posunu, který Dei verbum přebírá od Pia XII., je v naší koncilní konstituci patrné také to, že se koriguje $\mathbf{v}$ dané době velmi rozšířený názor, podle něhož tradice předává obsahově něco zjeveného, co v Písmu není obsaženo. Historické bádání však dokázalo, že na tridentském koncilu se střetly dva názory. Jeden, podle něhož by „traditiones“ obsahově překračovaly to, co nacházíme v Písmu, a druhý, podle něhož by „traditiones“ představovaly pouze jinou formu předávání téhož, co je obsaženo v Písmu. Když pak čteme pozorně výsledný věroučný text ze 16. století, zjištujeme, že koncilní otcové daný spor nechtěli rozhodnout a nechávají možnost obojího přístupu k dané problematice. ${ }^{47}$ Dlužno podotknout, že otcové shromáždění ve Vatikánu v první polovině šedesátých let minulého století tuto otázku také ponechali v zásadě otevřenou, nicméně je patrné, že se více kloní k mínění, podle něhož tradice předává totéž jako Písmo, ovšem jiným způsobem. Svědčí o tom například následující slova:

45 Srov. POSPÍŠIL, Ctirad V. Hermeneutika mystéria, s. 74.

46 Srov. TRIDENTSKÝ KONCIL (Sessio IV). Decretum de libris sacris et de traditionibus recipendis. Zde nacházíme text: „... hanc veritatem et disciplinam contineri in libris scriptis et sine scripto traditionibus, quae ab ipsius Christi ore ab apostolis acceptae, aut ab ipsis Apostolis Spiritu Sancto dictante quasi per manus traditae ad nos usque pervenerunt.“ DSH, č. 1501.

Původní forma dekretu, která ale nebyla schválena, obsahovala znění: „... hanc veritatem et disciplinam partim contineri in libris sacris, partim sine scripto in traditionibus." Srov. EHSES, Stephan (ed.), Concil Trident. V: Auctorum pars altera. Friburgi Br. 1911. s. 31. Tato verze by ovšem mohla naznačovat, že tradice toho říkají více, než je obsaženo v Písmu. Zvolené oficiální znění nahrazuje ono „zčásti - zčásti“ nevinným „a“, které jen těžko umožňuje, abychom jednoznačně tvrdili, že „tradice“ by obsahově říkaly něco více, než je obsaženo v Písmu.

Koncil tudíž v definitivním znění nezavrhuje jednoznačně princip „sola Scriput$r a “$. V roce 1561 kupříkladu vlámský kontroverzista G. Cassander zastával mínění, podle něhož „tradice“ vysvětluje a vyjevuje pravdy, které jsou více méně zahaleně obsažené v Písmu svatém. Srov. POLLMANN, Pontien. L'élément historique dans la controverse religieuse du XVI ${ }^{e}$ siècle. Gembloux: J. Duculot, 1932, s. 308. Je tedy zřejmé, že mínění, které silně omezuje obsahový přesah „tradicí vzhledem k Písmu, existoval již v době konání tridentského koncilu, jenž v závěrečné oficiální formulaci evidentně nechtěl danou záležitost jednoznačně řešit. 
„A tak apoštolské kázání, vyjádřené zvláštním způsobem v inspirovaných knihách, mělo být uchováno nepřetržitou posloupností až do konce věků.“48

Z řečeného vyplývá, že Písmo je vlastně zachycená a zredigovaná tradice prvotní církve a že tradice i Písmo předávají totéž, leč pokaždé svým vlastním způsobem.

V dané souvislosti je důležité si uvědomit, že magisterium nikdy neprohlásilo žádné dogma čistě na základě tradice, aniž by se vždy nesnažilo nějak odvolávat se na svědectví Písma. Zároveň ale argumentace na základě Bible byla v posledních staletích vždy doplněna argumentací dokládající trvalou přítomnost této pravdy v živé víre církve v průběhu věků, tedy na základě tradice. To se týká i posledních dvou mariologických dogmat, jejichž nauka sice není výslovně v inspirovaných knihách, leč teologové vynaložili nemalou iniciativu zaměřenou na prokazování implicitní přítomnosti těchto pravd v Novém zákoně, ${ }^{49}$ přičemž jsou př́tomny četné odkazy na svědky tradice. Živá víra tedy stojí na pomyslných dvou nohách, jimiž jsou Písmo a tradice. Katolická církev nikdy nečerpá svou nauku jen výlučně z jednoho z oněch zdrojů, nýbrž vždy z obou zároveň.

Koncilní otcové zmiňují pouze dva případy obsahového přesahu tradice nad Písmem, totiž rozpoznání kánonu inspirovaných knih a hlubší chápání Písma a jeho živou působnost. ${ }^{50}$ To je vcelku zřejmé, protože rozpoznání inspirovaných knih potřebovalo určité kritérium, jímž bylo právě apoštolské kázání, na němž stojí sama identita církve. Ona větší působnost Písma je také zřejmá, nebot text Božího slova se stává předmětem uctívání jedině tehdy, stává-li se toto psané slovo sloven živým, hlásaným a přijímaným ve společenství. Je totiž velký rozdíl mezi sdělovací silou na jedné straně psaného slova a živého a prožívaného - spoluprožívaného slova na straně druhé. Živé slovo se stává událostí, do níž se nepromítají pouze myšlenkové struktury,

48 2. VATIKÁNSKÝ KONCIL. Dei Verbum, čl. 8, s. 112.

49 Kupř́íkladu při argumentaci ve prospěch dogmatu o nanebevzetí Panny Marie se objevuje následující myšlenka: „Veškerá tato argumentace i úvahy svatých otců a teologů mají jako poslední základ Písmo svaté, které staví před oči vznešenou Matku Boží úzce spojenou se svým božským Synem a vždy mající účast na jeho údělu." PIUS XII. Munificentissimus Deus (1. listopad 1950), čl. 38. In POSPÍŠIL, Ctirad V. (ed.), Nanebevzetí Bohorodičky ve svétle dokumentů magisteria, Olomouc: MCM, 2000, s. 43-64. zde 60.

50 Srov. 2. VATIK ÁNSKÝ KONCIL. Dei Verbum, čl. 8, s. 113. 
ale také dějinná situace, v níž se nyní společenství nachází, a proto se slovo Boží staré dva tisíce a více let stává Božím slovem ted' a tady. ${ }^{51}$

Hovoříme-li o poměru mezi Písmem a tradicí, je vhodné připomenout, že Dei verbum o Písmu výslovně tvrdí, že je inspirované, což ale o tradici nikde neř́ká. O tradici se nepraví, že by byla Božím slovem, ale jasně se říká, že předává slovo Boží. Z tohoto hlediska by tradice byla podřazena Písmu. Zároveň ale z jiného úhlu pohledu je tradice více nežli Písmo, nebot' předává zjevení celistvě, totiž nejen jako nauku, nýbrž také jakou celkový souhrn prostředků, které nás zaměřují ke spáse. ${ }^{52}$ Zároveň je třeba velmi důrazně podtrhnout, že v Dei verbum se tradice zpravidla uvádí před Písmem a následně v některých případech také před magisteriem. ${ }^{53}$ Důvod je zřejmý: církev totiž může existovat určitou dobu bez knih Nového zákona, nemůže ale nikdy existovat bez živoucí tradice. Tradice tedy chronologicky Písmo předchází a je to ona, která ustavuje identitu církevního společenství.

Nyní se dostáváme k problematice vlastní povahy apoštolské tradice, o níž vypovídá mnohé následující text:

„A tak církev ve své nauce, životě a bohoslužbě trvale uchovává (perpetuat) a všem pokolením předává všechno, co sama je a v co věří.“54

V první řadě je třeba říci, že na tomto místě se do českého překladu vloudila nepřesnost. Výraz „perpetuat“55 je totiž tlumočen jako „zvěčňuje“, což neodpovídá pravému smyslu sdělení. Na jiných místech český překlad ono „perpetuare“ tlumočí nikoliv jako „Zvěčňování“, nýbrž jako „nepřetržité trvání“. ${ }^{56} \mathrm{Z}$ uvedeného důvodu si na tomto místě dovoluji navrhnout, aby český překlad byl upraven v tom smyslu, jak je to zde navrženo.

Je-li tradice jakožto předávané tím, co církev je a več věří, pak úzce souvisí s identitou církevního společenství v proměnlivosti

51 „A tak Bůh, který kdysi promluvil, nepřestává mluvit se Snoubenkou svého milovaného Syna a Duch svatý, skrze kterého zaznívá živý hlas evangelia v církvi a skrz nit také ve světě, uvádí věřící do veškeré pravdy..."2. VATIKÁNSKÝ KONCIL. Dei Verbum, čl. 8, s. 113,

52 Srov. BETTI, Umberto. La Dottrina del Concilio Vaticano II sulla Trasimissione della Rivelazione, s. 270-271.

53 Srov. 2. VATIKÁNSKÝ KONCIL. Dei Verbum, čl. 9-10, s. 113-114.

54 2. VATIKÁNSKÝ KONCIL. Dei Verbum, čl. 8, s. 113.

55 Srov. Enchiridion Vaticanum 1, č. 883.

56 Srov. např. 2. VATIKÁNSKÝ KONCIL. Lumen gentium, čl. 11, s. 48. 
časů. Jejím obsahem není tudíž pouze nauka, ${ }^{57}$ nýbrž sám nadpřirozený život z víry $\mathbf{v}$ církevním společenství. Tradice je tedy proud nadpřirozeného života, který se rozlévá $\mathrm{v}$ dějinách skrze hlásané a prožívané slovo Boží, svátosti, svědectví života (ortopraxe)... Tento přesah apoštolské tradice nad jejími konkrétními projevy v dějinách se projevuje i v tom, že v průběhu dějin vzrůstá chápání jejího obsahu. ${ }^{58}$ To by pochopitelně nebylo možné, pokud by se apoštolská tradice vyčerpávala $\mathrm{v}$ nějakém svém jednotlivém konkrétním historickém vyjádření.

Klíčovou je však otázka, jaký je poměr této tradice k jejím konkrétním projevům v dějinách. $\mathrm{V}$ dané souvislosti je zajímavé, že výroky svatých otců nemůžeme ploše identifikovat s tradicí, protože ony jsou pouze svědectvím o její oživující přítomnosti:

„Výroky svatých otců svědčí o oživující přítomnosti této tradice, jejíž bohatství se přelévá do praxe a života věřící a modlící se církve.“59

Mají-li se věci tak, jak tvrdí koncilní otcové, pak z toho ovšem nevyhnutelně vyplývá, že tato tradice má evidentně nadkulturní povahu, a proto na ni nelze pohlížet přes prisma oboru jménem kulturologie. Pojem apoštolské tradice je výlučně teologický, a nikoliv obecně kulturologický, nebot' je přístupný výlučně věřícímu, nikoliv kulturologovi, který je s to vnímat jen její jednotlivé časově a dobově podmíněné výrazové formy. Poměr mezi dějinně podmíněnými projevy př́tomnosti této tradice a apoštolskou tradicí samotnou je obdobný jako poměr mezi lidským rozměrem Písma a Biblí jakožto Božím slovem.

Pokud bychom jasně nerozlišovali apoštolskou tradici a její historicky a kulturně podmíněné výrazové formy, pak by nevyhnutelně vyvstala otázka, jak by tato apoštolská tradice dokázala - jakožto identita církev - sjednocovat v diachronním i synchronním rozměru věřící různých kultur? Zároveň ale tato sjednocující a křest́anskou identitu pravé církve nesoucí tradice musí existovat v pluralitě a proměnlivosti výrazových kulturních prostředků. Katolicita přece

57 „Tradice není tolik souborem termínů, ale spíše souhrnem skutečností.“ BETTI, Umberto. La Dottrina del Concilio Vaticano II sulla Trasimissione della Rivelazione, s. 257.

58 Srov. 2. VATIKÁNSKÝ KONCIL. Dei Verbum, čl. 8, s. 113.

59 Tamtéž. 
není uniformita, nýbrž přesně naopak rozličnost v jednotě a jednota v rozličnosti, což obráží věčný pravzor církevního společenství, jímž je sama Nejsvětější Trojice. ${ }^{60}$

Na tuto skutečnost poukazovali již někteří koncilní otcové, když projevili přání, aby se do druhé kapitoly Dei verbum promítlo jasnější rozlišení mezi apoštolskou tradicí na jedné straně a tradicemi církevními na straně druhé. ${ }^{61}$ Odpovědět na otázku, proč se toto velmi důležité rozlišení nakonec přímo do definitivního textu nepromítlo, se nezdá být tak složité: $V$ tehdejší době ještě nebyla tematika inkulturace dostatečně propracována, ${ }^{62}$ a proto by daná záležitost zřejmě u řady koncilních otců mohla způsobit určité rozpaky. Nezapomínejme na

60 Srov. 2. VATIKÁNSKÝ KONCIL, Lumen gentium. čl. 4, s. 39.

61 Srov. BETTI, Umberto. La Dottrina del Concilio Vaticano II sulla Trasimissione della Rivelazione, s. 174. Na tomto místě se prezentuje obsah Doktrinální komise, která vyslovila v průběhu třetího sněmovního období (14. září - 21. listopadu 1964) k navrhovanému znění konstituce Dei verbum.

62 Dlužno podotknout, že o tomto tématu se hovořilo již před koncilem. Kupříkladu V. G. VANZIN, ve svém díle L'evangelizzazione delle culture, Parma 1958 hovořil o nutností „vtělovat“ evangelium do jiných kultur. V první etapě byla inkulturace vnímána především jako misiologický problém. Inkulturace by se tedy týkala přednostně, ba výlučně mimoevropských kultur. Srov. např. CONGAR, Yves. Christianisme comme foi et comme culture. In Evangelizzazione e cultura I. Roma: Urbaniana University Press, 1975, s. 83 nn.

Učitelský úřad katolické církve začíná oficiálně tohoto pojmu používat až v roce 1979, kdy Jan Pavel II. ve svém proslovu k členům Papežské biblické komise hovořil o „inkulturaci“ i o „akulturaci“ Božího zjevení (dne 26. dubna 1979). V té době nejvyšší pontifik používal oba výrazy, jako by se jednalo o synonyma. Od roku 1980 však Jan Pavel II. užívá výhradně pojmu „inkulturace“. Zásadním příspěvkem v této oblasti jsou reflexe obsažené v encyklice Redemptoris missio. Vedle toho by bylo možno jmenovat dlouhou řádku dokumentů Svatého stolce, které se zabývají problematikou mimokřestanských náboženství, mezináboženským dialogem a hlásáním evangelia. Srov. DHAVAMONY, Mariasusai. Inculturazione. Riflessioni sistematiche di antropologia sociale e di teologia cristiana. Cinisello Balsamo: San Paolo, 2000, s. 109. Teprve později dospívají teologové k jasnějšímu vědomí, že inkulturace se týká i samotného západního světa a že se jedná o zásadní problematiku pronikající celou teologickou reflexí. Srov.: DE CARAVALHO AZEVEDO, Macello. Inkulturace a požadavky modernosti. In DE CARAVALHO AZEVEDO, Macello (ed.). Inkulturace a požadavky modernosti. Olomouc: Refugium, 2000, s. 29-65; MEZINÁRODNÍ TEOLOGICKÁ KOMISE. Víra a inkulturace. In POSPÍŠIL, Ctirad V. (ed.). Dokumenty MTK věnované metodě do roku 1995 a statuta MTK. Kostelní Vydří: Karmelitánské nakladatelství, 2011, s. 54-80 dokument pochází z roku 1988. Srov. také POSPÍŠIL, Ctirad V. Služba teologie kultuře (teologie v kultuře) a kultura jako teologické téma (kultura v teologii). In PASTUSZAK, Jaroslav (ed.). Krest'anství a kultura - Védecký seminár poŕádaný Katedrou pastorální a spirituální teologie CMTF UP v Olomouci uskutečnèný dne 12. 11. 2003. Olomouc: CMTF UP, 2004, s. 16-37. 
to, že cílem jednání bylo dosažení co nejjednomyslnějšího souhlasu shromážděných koncilních otců.

Toto $\mathrm{v}$ jistém slova smyslu „dvoustupňové“ chápání tradice nám následně umožňuje dobře rozlišovat trvalé od proměnlivého v životě církve. Například slavení eucharistie je jednoznačně tradice apoštolská, zatímco formy jejího slavení jsou konkrétními eklesiálními tradicemi, které jsou pochopitelně proměnlivé. Ukazuje se tedy, že $\mathrm{k}$ apoštolské tradici nemáme nikdy přístup v její krystalické formě, protože ji vnímáme výlučně přes prisma jejích projevů v dějinách právě na rovině tradic eklesiálních. To je také jeden z hlavních důvodů, proč poznání apoštolské tradice v dějinách narůstá, s postupem času totiž máme k dispozici větší počet jejích vyjádření, a tak si jasněji uvědomujeme její skutečný nadkulturní obsah.

Vedle eklesiálních tradic ${ }^{63}$ spjatých s apoštolskou tradicí se ovšem v životě církve střetáváme také s eklesiálními tradicemi, jež jsou vůči té apoštolské neutrální, ba dokonce i s takovými, které jsou s apoštolskou tradicí v rozporu. Zde se otvírá pole pro ustavičnou reformu církve, která přece neustále potřebuje být obnovována vzhledem ke své nejhlubší identitě. ${ }^{64}$

To, co jsme právě řekli, nám umožňuje být jak pevně zakotveni v tradici apoštolské, ta také být plnoprávně a doopravdy lidmi své vlastní doby, stejně jako takovými lidmi byli sám Kristus a apoštolové. Být zdravě katolicky tradiční proto rozhodně neznamená zkostnatělost a předpotopnost. Jestliže fundamentalistická lektura Písma neuznává lidskou „přirozenost“ Písma, a proto $\mathrm{v}$ tomto případě můžeme hovořit o jakémsi skripturistickém „monofysitismu“, pak

63 Na tomto místě bych si dovolil poznámku, která se týká českého pravopisu. Původci českého překladu již vícekrát zmíněného dokumentu Verbum Domini, který je jinak velmi pěkný, se podle mého soudu dopouštějí nepřesnosti v psaní velkých počátečních písmen, když kopírují úzus originálního znění. V češtině „Slovo Boži“ znamená vtěleného Syna, zatímco „slovo Boži“ označuje Písmo svaté. Nerespektování tohoto rozlišení, s nímž se v českém překladu uvedeného dokumentu setkáváme velmi často, je evidentně na závadu srozumitelnosti. Pokud se jedná o psaní výrazu „Tradice“, bylo by to vcelku logické psát toto slovo s velkým písmenem na začátku, jak to činí již vícekrát zmínění překladatelé. Pokud by se ovšem jednalo o tradice eklesiální, už by to tak logické nebylo. Právě jsme ukázali, že prakticky není možno vždy jasně rozlišit, o kterou tradici se jedná, protože ta apoštolská se vždy projevuje v nějaké konkrétní tradici eklesiální, která by se každopádně měla psát s malým počátečním písmenem. Navíc střídání malého a velkého počátečního písmene u téhož výrazu by činilo mnoha lidem obtíže. Z uvedených důvodů se proto přikláním k pravopisu, který aplikovali překladatelé koncilních dokumentů do češtiny, totiž psát slovo „tradice“ vždy s malým počátečním písmenem.

64 Srov. POSPÍŠIL, Ctirad V. Hermeneutika mystéria, s. 74-76. 
cosi obdobného platí o analogicky „fundamentalistickém“ a v jistém ohledu „fideistickém“ tradicionalismu, který nerespektuje fakt, že apoštolská tradice se musí vtělovat do naší doby a kultury. V obou případech pak schází zralá otevřenost transcendenci Božího slova. Dospělý katolický křesțan rozhodně není člověkem, který se bojí nadcházejícího času, jak kdesi napsal pan Vančura, i když bohužel při pohledu na některé ne právě zralé věřící dospíváme k závěru, že Vančurovo tvrzení bohužel není zase tak zcela nemístné.

Když se v roce 2010 objevila posynodní apoštolská exhortace Benedikta XI., Verbum Domini, byla to příležitosti reflektovat právě zmíněná prohloubení v oblasti chápání apoštolské tradice. Bohužel články 17 a $18^{65}$ nepřinášejí v tomto ohledu zhola nic nového a koncilní nauka se v nich vủbec nerozvíjí. Tím ale nemíním tvrdit, že daný dokument nepřináší zhola nic nového, jak jsme to již měli možnost několikrát konstatovat $\mathrm{v}$ průběhu našeho snažení. Jednou z takových inspirací, která jde v určitém ohledu nad to, co nacházíme v Dei verbum, nacházíme v článcích 27-28, kde se setkáváme s výzvou, abychom „více prohloubili vztah mezi mariologií a teologií Slova.“66 A právě o tom se zmíníme v následujícím bodu.

\section{Mariologické prohloubení reflexe nad tajemstvím Božího slova}

Dei verbum neobsahuje přímou rozvahu nad poměrem mezi tajemstvím zjevení a tajemstvím Matky vtěleného Božího Syna. Přesto zde nalezneme dvě implicitní mariologické inspirace.

O první jsme se již zmínili v souvislosti s tím, že inspirované Boží slovo Písma je na základě analogie víry přirovnáváno k samotnému vtělenému Slovu, které má božskou i lidskou přirozenost. ${ }^{67}$ Ačkoliv to koncilní otcové přímo neříkají, můžeme z toho snadno vyvodit, že inspirace a sepsání slova Božího ze strany lidského autora je určitou analogií početí a porození vtěleného Slova ze strany Marie z Nazareta.

65 Srov. český překlad - Kostelní Vydří: Karmelitánské nakladatelství, 2011, s. 34-36.

66 BENEDIKT XVI. Verbum Domini, s. 44.

67 2. VATIKÁNSKÝ KONCIL. Dei Verbum. čl. 13, s. 116. 
Druhá implicitní mariologická inspirace je př́ítomna ve slovech:

„Tato apoštolská tradice prospívá církvi s pomocí Ducha svatého. Vzrůstá totiž chápání předaných věcí a slov, a to jak přemýšlením a studiem věřících, kteří je uchovávají ve svém srdci (srov. Lk 2,19.51), tak hlubším pochopením duchovních skutečnosti z vlastní zkušenosti.“68

Je evidentní, že odkaz na 2. kapitolu Lukášova evangelia je přímou narážkou na Mariin postoj k Božímu tajemství, které se postupně zjevuje v životním příběhu jejího Jednorozeného. Ona je jak Matka, tak Učednice.

Když pročítáme výše zmíněné pasáže v dokumentu Verbum Domini, nebýváme dojmu, že Maria je pouze učednicí, a proto jen vzorem recepce Božího slova. Vyvstává otázka, zda se poněkud nezapomíná na její aktivní roli matky vtěleného Slova. Vezmeme-li v úvahu, že existuje výrazná analogie mezi postavou Marie z Nazareta na jedné straně a Kristovou církví na straně druhé, pak se nabízí následující doplnění.

Autorství knih Písma se až doposud výrazně vázalo na osoby svatospisců, přičemž se zapomínalo na skutečnost, že oni psali v církvi a pro církev a že to byla zase církev, která rozpoznala (rozhodně ne určila!!!) inspirovaný charakter těchto spisů. Z tohoto hlediska je tedy církev spoluautorkou Písma, ${ }^{69}$ a proto je také nositelkou autentického výkladu zjevení. To ale neznamená, že církev by stála nad Písmem. Její poměr k Písmu je totiž analogický se vztahem Marie ke Kristu: Církev je matkou Božího slova co do jeho lidské přirozenosti, ale zároveň je jeho učednicí, stejně jako Maria, která dala vtělenému Slovu jeho lidství, což obnáší i výchovu, a následně ho ve víře přijala jako Mesiáše a pravého Božího Syna.

\section{Závěr}

Není sporu o tom, že dogmatická konstituce II. vatikánského koncilu Dei verbum představuje trvalý referenční bod současné katolické teologické reflexe a že nauka v tomto dokumentu obsažená vykazuje

68 2. VATIKÁNSKÝ KONCIL. Dei Verbum. čl. 8, s. 113.

69 Tomu, co jsem právě řekl, se blíží výrok Benedikta XVI. „Boží lid, církev, je živoucím subjektem Písma; v něm jsou biblická slova vždy př́ítomností.“ BENEDIKT XVI. Ježiš Nazaretský, díl I. Praha: Barrister \& Principal, 2007, s. 11. 
nezanedbatelná prohloubení a vyjasnění vzhledem k chronologicky předchozím výrokům učitelského úřadu katolické církve. Zároveň ale musíme konstatovat, že bezmála padesát let od jejího vzniku přineslo celou řadu posunů, které by teolog měl brát vážně v potaz. Největším takovým impulsem při promýšlení tajemství tradice je rozvinutí reflexe, která se týká inkulturace, což nás vede k jasnějšímu rozlišování apoštolské tradice od různých tradic eklesiálních. S tím je spjata také nesporně vyšší hermeneutická úroveň současné teologické reflexe a domýšlení poměru mezi dějinně podmíněným a nadčasovým.

Dalším tématem, které si zasluhuje důkladnějšího promyšlení, než jaké nám skýtá analyzovaný text, je poměr mezi nadpřirozeným a přirozeným zjevením, případně poměr mezi přirozenou teologií a teologií stavějící na Božím slovu.

Ne právě snadnou otázkou se ukazuje být přesné vymezení dogmatické závaznosti Dei verbum. Podle našeho mínění by se mělo jednat o nejvyšší úroveň tak zvaného „třetího koše“. V dané souvislosti by bylo třeba v následující edici dokumentů II. vatikánského koncilu doplnit překlad „Notificatio“ ze dne 15. listopadu 1965, kde se nachází určitá ne právě jasná odpověd' na právě položenou otázku.

Nikoli v poslední řadě se ukazuje, že v Dei Verbum není dostatečně zohledněna otázka mariologických inspirací, které nám mohou napomoci k hlubšímu porozumění tajemství zjevení a jeho recepce.

Dlužno ještě podotknout, že český překlad čl. 8 vyžaduje materiálně sice nepatrnou, leč z významového hlediska ale velmi závažnou korekturu, o níž jsme se zmínili výše v textu. Bývá ještě zvykem, že edice koncilních dokumentů mívá jako doplněk dokument Papežské biblické komise $O$ historické vérohodnosti evangelii. Na tomto místě si dovolím zájemce upozornit, že existující český překlad tohoto ve své době přelomového dokumentu je zájemcům k dispozici na webových stránkách České christologické a mariologické akademie (www.cchma.cz). 


\section{RESUMÉ \\ CTIRAD VÁCLAV POSPÍŠIL \\ Selected Inspiration Contained in the First Three Chapters of Dei Verbum Fifty Years After the Start of the Council}

The contribution of this article is twofold. Firstly, the author points out the basic inspiration contained in the first half of Dei verbum. Secondly, he also highlights the further development of theological reflection in the field. This enquiry reveals the weak points of Dei verbum such as the issue of the so-called natural revelation and a deeper reflection on the possibility of Mariological inspirations in the field of the theology of word. Furthermore, the development of theological hermeneutics in general and the theological problem of inculturation in particular represents the most profound shift in the last fifty years. This shift must be reflected as a complementary perspective to what Dei verbum teaches about the apostolic tradition. Indeed, it is necessary to clearly distinguish the apostolic tradition (which is 'above' cultures) from ecclesial traditions ('within' cultures). The author further suggests some changes in the Czech translation of the text of the constitution. Moreover, he stresses the importance of the "Notification" which specifies the authority of the constitution and the document on The Historicity of the Gospels issued by the Pontifical Biblical Commission.

Key words

Vatican II, Revelation, Tradition 
